\title{
Philoponus on the Nature of the Heavens and the Movement of Elements in Against Aristotle on the Eternity of the World
}

\author{
Maria Varlamova \\ Saint Petersburg State University of Aerospace Instrumentation \\ boat.mary@gmail.com
}

\begin{abstract}
This paper deals with the John Philoponus' arguments against the eternity of the heavens in context of the dispute against the eternity of the world. The theory of eternity of the heavens was defended by Aristotle in his Physics and in the 1st book On the Heavens. In his treatise On Eternity of the World against Aristotle Philoponus attacks the arguments of Aristotle in order to prove the essential finititude of the heavens. The Philoponus' arguments are related to the nature and motion of elements and especially to the nature of fire. In order to explore the Philoponus' arguments against Aristotle I compare his doctrine with the Aristotle's theories of elemental nature and celestial motion.
\end{abstract}

\section{Keywords}

eternity of the heavens - elements - aether - fire - movement - Philoponus Aristotle

* The present study is a part of the project Nr. 16-03-00047, "Nature and movement in the 'Commentaryon the Physics of Aristotle' by Michael Psellos. Study of the influence of the late antique tradition, of the correlation between physics and the Orthodox theology, and of the reception in the later Peripatetic physics", implemented with a financial support of the Russian Foundation for Basic Research. 


\section{Introduction}

Out of all polemical works of Philoponus, On Eternity of the World Against Proclus is the most famous one, since it has been preserved in near entirety. However, Simplicius, the main opponent of Philoponus, considered the work $\mathrm{On}$ Eternity of the World against Aristotle to be more significant. By his own admission, Simplicius did not even bother reading the work against Proclus, ${ }^{1}$ but he did narrate and challenge the key points of Philoponus' work against Aristotle in his own commentary on Aristotle's On the Heavens. The largest part of Philoponus' treatise is dedicated to proving the fundamental finititude of the heavens. This issue is of such high importance, because the eternity of the heavens is one of the key arguments in defense of the eternity of the world. The heavens are understood as a certain part of the universe as well as something that on one hand, makes the world whole and on the other hand, is the reason for constant movement in the sublunary world. Therefore, in order to prove that world was created, Philoponus must likewise prove that the heavens were created and can be destroyed.

The following article is going to first of all, look at Philoponus' arguments against the commonly-held view in cosmology of the Antiquity according to which, the heavens are eternal; these arguments can be found in On the Eternity of the World against Aristotle and correlate with the way he viewed celestial matter. Secondly, the article will compare these views with those of Aristotle to see what kind of changes in understanding of world's structure and views on elements and matter underpin Philoponus' arguments. Of course the discussions on the structure of the heavens have a rich history in the Antiquity. ${ }^{2}$ In one way or another, the questions concerning the movement of the heavens and the heavenly matter were delved into by the Neoplatonists, Aristotelians and Stoics. However, the following article will limit itself to comparing Aristotle and Philoponus, since the latter refers in the aforementioned work directly to Aristotle. Other reason for such limit is the analysis of the whole context of the argument is barely possible in the limited format of a research article. That is why the author will not go into the Neoplatonist component of the discussions on the heavens and instead, will focus on analyzing the criticism directed

1 Simplicius. In de Caelo, in: I.L. Heiberg, Simplicii In Aristotelis de Caelo commentaria (Commentaria in Aristotelem Graeca, VII), Berlin, 1894, p. 135, 27-31.

2 See C.В. Месяц, “Дискуссии об эфире в античности” in: Космос и душа. Учения о вселенной и человеке в античности и в средние века, изд. П. Гайденко, В. Петров, [S. Mesyats, “Antient discussions on aether" in: Cosmos and Soul. Teachings on the univerce and man in Antiquity and the Middle Ages, ed. P. Gaidenko, V. Petrov,], Moscow, 2005, pp. 63-113. 
at Aristotle. This criticism by itself is of high significance, since it allows to point out some changes in terminology, i.e. the difference in understanding a number of fundamental terms in physics. ${ }^{3}$

\section{Arguments and Counter-Arguments in the Discussion on the Eternity of the World}

Aristotle sees the heavens not simply as one of the parts of this world but also as something whole or as something that makes the world whole. He contrasts the movement of the heavens with the movement of sublunary things not only as something that is different by virtue of having more dignity and perfection, but also as the movement of a whole related to its parts. In the cosmology of Aristotle, the heavens are the extreme sphere of the world, outside of which there is nothing: neither matter, nor a place, nor a thing. Instead, the heavens

3 On the Eternity of the World against Aristotle was compiled and published as a separate treatise only in English with translation by Christian Wildberg with his commentaries. See:Philoponus: Against Aristotle on the Eternity of the World, reconstr. and trans. C. Wildberg, London, 1987. Wildberg also wrote a separate book, in which he analyzes Philoponus' argumentation in comparison with that of Aristotle (C.J. Wildberg, Philoponus' Criticism of Aristotle's Theory of Aether. Berlin, 1988). Although there are a number of works dedicated to the discussion on the eternity of the world and the analysis of Philoponus' view on the composition of the world as well as a number of fundamental questions of physics. See: R. Sorabji, Matter, Space, and Motion, London, 1988, pp. 227-248; R. Sorabji, "Infinite Power Impressed: the Transformation of Aristotle' Physics and Theology", in: Aristotle Transformed, ed. R. Sorabji, London, 1990, pp. 181-199; R.Sorabji, "John Philoponus", in: Philoponus and the Rejection of Aristotelian Science, 2nd edition, ed. R. Sorabji, London, 2010, pp. 1-81; R. Sorabji, "The Ancient Commentators on Arisototle", in: Aristotle Transformed, ed. R. Sorabji, London, 1990, pp. 1-31; R. Sorabji, Time, Creation and the Continuum, London, 1983. pp. 193-231; F.A.J. de Haas, John Philoponus' New Definition of Prime Matter, Leiden, 1997; C. Scholten, Antike Naturphilosophie und christliche Kosmologie in der Schrift "De opificio mundi" des Johannes Philoponos, Berlin, 1996; M. Wolff, Fallgesetz und Massebegriff. Zwei wissenschaftshistorische Untersuchungen zum Ursprung der klassischen Mechanik, Berlin, 1971; M. Wolff, Geschichte der Impetustheorie. Untersuchungen zum Ursprung der klassischen Mechanik. Frankfurt/M., 1978; M. Wolff, "Philoponus and the Rise of Preclassical Dynamics", in: Philoponus and the Rejection of Aristotelian science, ed. R. Sorabji, 2nd edition, London, 2010, pp. 125-160; L. Judson "God or Nature? Philoponus on Generability and Perishability", in: Philoponus and the Rejection of Aristotelian science, ed. R. Sorabji, 2nd edition, London, 2010, pp. 221-239; H.S. Lang, The order of Nature in Aristotle's Physics: Place and The Elements. Cambridge, 1998; and others. The treatise against Aristotle itself is insufficiently studied. In the following article, we will attempt to show Philoponus' arguments, take his criticism of aether theory and include Philoponus' theory of matter and nature. 
themselves form the entirety of a place, in which moving physical bodies are located. The movement of the lower celestial spheres, the movement of stars and of the sun and hence the change of natural phenomena and seasons - all depend on the movement of the heavens. That is why the movement of the heavens allows for the eternity of movement in the world and thus, the eternity of the heavens allows for an eternal existence of sublunary world. The heavens are indestructible, because they move circularly, which can go on forever and which is by nature characteristic of a special matter - aether. Aether is a matter that is different from other four sublunary types of matter; and unlike others - it is not generated and therefore, cannot be destroyed. ${ }^{4}$

Aristotle looks at the question of the eternity of the heavens in Physics, On the Heavens and in Meteorology. However, Philoponus' criticism is directed first and foremost at the arguments laid out in the 2-4 chapters of the first book On the Heavens, where Aristotle rejects Plato's idea that the heavens can be made out of fire ${ }^{5}$ and introduces aether, the fifth element separate from other elements, as the celestial matter. These arguments can be shortly summarized as follows:

1. There exist two simple movements: in a straight line and in a circle; furthermore, a simple straightforward movement is subdivided into two opposites: upward movement and downward movement. Each simple body by its nature moves with one simple movement. Thus, for instance, earth and water move downward or to the center of the universe, while fire and air move upward. If fire by its nature moves upward, then the movement in a circle cannot be by nature inherent to it; therefore, it is contrary to its nature.

2. Circling movement is more complete, because a circle is a complete shape unlike, say, a line, which can be continued into infinity. ${ }^{6}$ Simple movement pertains to a simple body, while the most primary and most perfect out of all simple movements pertains to the most perfect body. If movement in a straight line pertains to simple bodies, then circular movement must also pertain to a simple body; this body, however, must differ from other elements. Thus, based on the idea of circular movement's perfection, Aristotle makes a conclusion about the prominence of the heavenly substance: "These premises clearly give the conclusion that

\footnotetext{
4 Since elements are simple bodies, then alteration, i.e. change in respect of quality, would mean transformation into some other element and consequently - destruction.

5 Cf. Plato, Timaeus, 32b 8-33.

6 Aristotle, De Cael., 269a 18-28.
} 
there is in nature some bodily substance other than the formations we know, prior to them all and more divine than they". ${ }^{7}$

3. Any movement occurs either according to nature or contrary to it. What occurs according to nature for one body can occur contrary to nature for another. Circular movement is contrary to elemental nature and therefore, must pertain to the nature of another body.

4. If circular movement pertains to a body according to its nature, then among simple bodies there should be such a body that is able to move in a circle by its nature, just as fire is able to move upward and earth - downward; such body is called aether. A body that moves in a circle cannot move contrary to its nature, since then its movement would not be constant and eternal. Since fire moves upward, the movement in a circle is contrary to its nature and therefore, the heavens cannot be made up of fire.

5. There is no lightness of heaviness in a body that moves in a circle, and therefore, it cannot move upward or downward neither according nor contrary to its nature. ${ }^{8}$

6. A heavenly body does not have any opposites since first of all, circular movement does not have an opposite movement and second of all, there is no element that is an opposite of aether. Since in order to generate a body there must be an opposite (because it generates from an opposite and is corrupted into an opposite; for instance, something hot is generated from something cold), a body that does not have any opposites cannot be generated or be corrupted.

Thus, Aristotle proves that "there is something beyond the bodies that are about us on this earth, different and separate from them; and that the superior glory of its nature is proportionate to its distance from this world of ours". ${ }^{9}$ This body is called the heavens and by its nature it is not generated or corrupted; it moves in a circle and sustains a constant generation of beings in the sublunary sphere. Since the heavens are by nature eternal, so then also the cosmos as a whole has no beginning in time.

As a whole, all of Philoponus' arguments in the treatise against Aristotle are aimed to prove that the world has a beginning and can be destroyed. These arguments can be divided into four groups:

7 Ibid., 269a 30-33, cited in transl. by J.L. Stocs in: J.L. Stocs, Aristotle. On the Heavens <http:// classics.mit.edu/Aristotle/heavens.1.i.html>.

8 Ibid., 270a 10-11.

9 Ibid., 269b 15-18, cited in transl. by J.L. Stocs in: J.L. Stocs, Aristotle. On the Heavens. 
1. Arguments concerning the movement of the heavens. Philoponus denies the superiority of circular movement over straightforward one and proves that circular movement is present even in the sublunary sphere, which means that this cannot be the reason to consider the heavens as something divine.

2. Arguments concerning celestial matter. Philoponus denies the existence of aether as a special matter, different from sublunary things. He proves that the heavens are composed out of sublunary elements (predominantly fire) and hence, puts the heaves in line with other natural things that by their nature and matter can be destroyed.

3. Arguments concerning the essential finitude of movement. Philoponus insists that time and movement as a whole cannot last forever but must have a beginning and an end. This proves that a moving body cannot preexist prior to movement in time, and that movement can appear as a relation between the mover and that being moved, hence one or the other must pre-exist. ${ }^{10}$

4. Arguments concerning generation out of nothing based on a certain understanding of nature of the world and God. Nature cannot create a thing out of nothing, since natural things does not appear by itself out of nothing but appears out of substrate matter. By contrast, God, who unlike nature can create a thing out of nothing, while at the same time creating its form and matter and causing its movement; such a creature will not be a process in time, since God Himself exists outside of time. ${ }^{11}$

The article will further deal with the first two groups of arguments, mainly with the arguments concerning the materiality of the heavens. Consider Philoponus' objections to the aforementioned arguments of Aristotle:

1. There is no need for nature to be the principle of a natural body's sole movement; a body of one nature can have two movements. That is why fire can move both upward and in a circular fashion.

2. A complete movement has a beginning, middle and end. Movement in a straight line actually has a beginning, middle and end, whereas circular movement has these only in potentiality, which means that one can pick a certain point on a circle as the beginning of movement. That is why

10 Simplicius, In Phys., in: H. Diels, Simplicii In Aristotelis Physicorum libros quattuor priores commentaria (Commentaria in Aristotelem Graeca, IX), Berlin, 1882, pp. 147, 10-151, 21.

11 Simplicius, In Phys., in.: H. Diels, Simplicii In Aristotelis Physicorum libros quattuor posteriors commentaria (Commentaria in Aristotelem Graeca, X), Berlin, 1895, p. 1150, 16-25. 
movement in a straight line is more complete that movement in a circle. It should be noted here that Aristotle proceeds from a geometric figure, since a geometric line is not complete because it can be continued further and further, whereas Philoponus proceeds from a physical movement: movement in a straight line always has an end, which means that this movement is a more complete one. ${ }^{12}$ Therefore, if circular movement is not a more complete one, then the heavens that move in a circle should be understood as something divine.

3. Philoponus agrees that the heavens do not have lightness or heaviness and cannot move upwards or downwards. However, he proposes another composition of the heavenly matter by virtue of which the heavens lose their divine status. Although the heavens consist of fire, they do not have lightness to them, because fire in its natural place, i.e. above, loses its lightness as a natural inclination ( its inclination once it reaches its natural place.

4. The celestial body is not a subject to alteration but this does not mean that it can be destroyed. On one hand, the heavens do not have any particular distinguished matter but are composed from the same matter, out of which all things under the heavens are made out of. On the other hand, the heavens, as any other natural thing, are composed of form and matter and, being a composite thing, it is limited and is finite by its very nature. Thus, according to its matter and essence, the heavens have to be generated and can be corrupted.

\section{Fire as Matter of the Heavens}

Discussions concerning matter of the heavens have a long history in the Antiquity. For instance, in his work Against Proclus Philoponus mentions that Theophrastus defended the aether theory, ${ }^{13}$ whereas his successor Strato denied the existence of the fifth element. ${ }^{14}$ Strato is backed up by Xenarchus, a peripatetic of the first century $\mathrm{CE}$, who wrote a separate treatise against the existence of

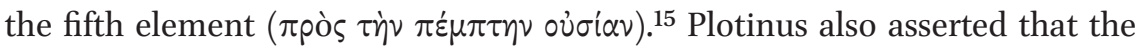

12 Aristotle, Phys., 265a 15-25.

13 Philoponus, Contr. Pr., in.: H. Rabe, Ioannes Philoponus. De Aeternitate mundi contra Proclum, Leipzig, 1899, p. 520, 18-23.

14 Strato, fr. 84, in: F. Wehrli. Strato, Basel, 1950.

15 A. Falcon, Aristotelianism in the First Century BCE. Xenarchus of Seleucia, Cambridge, NY, 2012, p. 63 . 
heavens are made not of aether but of fire. Simplicius accuses Philoponus of copying this arguments from Xenarchus. ${ }^{16}$ The context of Philoponus' arguments, however, is drastically different, since he criticises the aether theory as part of his refutation of the eternity of the world, whereas for the Peripatetics and Platonists the discussion on celestial matter was not connected with the issue of world's finitude.

It must be pointed out that Philoponus, following the whole tradition, maintains that the heavens are the first in dignity and as the most perfect part of the world, remain unchanging in its parts and as a whole throughout world's existence. ${ }^{17}$ This means that during their movement, they do not undergo qualitative changes, they cannot transform into some other, non-celestial state or be corrupted. However, it is important for Philoponus to prove that the heavens like any other things, can be generated and can be destroyed, i.e. its essential finitude. ${ }^{18}$ For this reason, he strives to show that the heavens correlate with sublunary things, demonstrating that the celestial and sublunary spheres share the same matter.

It is important to remember that Aristotle's thoughts on aether are based on the theory, which says that for each simple body (i.e. element) there is by nature an inherent movement in place; this movement must be simple: elements move either downward or upward or in a circle. Philoponus first and foremost insists that the difference in movements does not necessarily lead to difference in natures:

If [bodies] that are different in nature like earth and water can move with the same movement ... there is nothing to prevent [bodies] which move with a different and not the same movement from being of the same nature, so that, even if the heavens move in a circle but the [bodies] below the moon [move] in a straight [line], still there is nothing to prevent the heavens from being of the same nature as the sublunary [bodies] and perishable like them. ${ }^{19}$

Here Philoponus differentiates between the nature of an element as a simple body from its movement by pointing out that bodies of the same nature can

\footnotetext{
16 Simplicius, In de Cael., 25, 22-24; 26, 31-33.

17 Ibid., 142, 7-25.

18 C.J. Wildberg, Philoponus' Criticism, p. 232.

19 Simplicius, In de Cael., 28, 7-11, cited in transl. by J. Wildberg in: C.J. Wildberg, Philoponus: Against Aristotle, pp. 44-45.
} 
move differently, that is to say a single element can by nature have two movements.

However, two opposite movements cannot be inherent to a single body. Thus, one single body cannot by nature move both upward and downward; on the contrary, if a body moves upward by nature, then a downward movement will be contrary to its nature. If a circular movement is not opposed to a straightforward one, then one and the same body can inherently move in a straight line and in a circle. ${ }^{20}$ This argument fits in with the general understanding of elemental places in the cosmos. Following Aristotle, Philoponus asserts that elements have their own natural places and that some part of an element always resides in its natural place. Earth is located in the very middle of the universe, water is higher, air is even higher and in the highest place resides fire. Moreover, the totality of a simple body in its natural place can have qualities that are different from qualities of elemental parts, which are removed from a natural place. Thus can be seen in the case of fire:

Fire has two natural movements, the one in an upward direction [which belongs to] the parts of [fire] which have become detached from the totality, the other, a circular one, [which belongs to] the totality itself, so that there is nothing to prevent the revolving heaven itself from consisting if fire, and the movement will not be contrary to its nature. ${ }^{21}$

According to Simplicius, Xenarchus supposed that a body in its natural place reaches its actualization in ability for motion. This means that heaviness and lightness as qualities are always inherent to a body but when it is removed

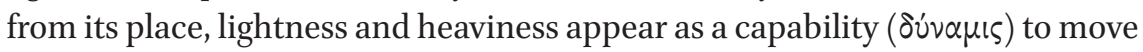
toward its proper place, and when it reaches that place, they become an actuality. In addition, according to Xenarchus, an element in its natural place either rests or moves in a circle. Earth, water and air are resting, while fire is moving in a circle as well as makes up the matter of the celestial sphere. ${ }^{22}$

By contrast, according to Philoponus, the sum of elemental parts located in its natural place does not possess lightness or heaviness and as consequence, the capability to move upward or downward, but instead is always resting, rela-

\footnotetext{
20 Simplicius, In de Cael., 34,34 - 35,8.

21 Ibid., 35, 15-17, cited in transl. by J. Wildberg in: C.J. Wildberg, Philoponus: Against Aristotle, p. 48 .

22 Ibid., 21,33 - 22,17; see also A. Falcon, Aristotelianism in the First Century BCE, p. 107, P. Moraux, Der Aristotelismus bei der Griechen, Bd. 1: Die Renaissance des Aristotelismus im I. Jh. v. Chr, Berlin, 1973, p. 199.
} 
tive to these movements. ${ }^{23}$ Lightness and heaviness as qualities and abilities for movement are inherent only to those elemental parts that are removed from their natural place; ${ }^{24}$ these qualities are not native to the elements but instead they are relative qualities which depend on elemental location and reflect the way elements are related to each other. For instance, both water and earth tend to go downward, though water is lighter than earth.

The [Grammarian] infers that heaviness and lightness do not belong to the elements as such. "For [otherwise] it would not be the case," he says, "that the same [elements], [endowed] with the same capacities and having received nothing in addition from outside, are in fact light in one place and heavy in another only because of their relation towards each other, and [that they are] light in relation to one, but heavy in relation to another [element]". ${ }^{25}$

Parts of simple bodies that are removed from their natural places, have an inclination for upward or downward movement, i.e. is inclined to their natural place. In contrast to Xenarchus, Philoponus thinks that circular movement is characteristic of light bodies that have reached their natural place, which means that not only fire but also air move in a circle: "Both the firesphere and the air move in a circle [and they possess] this movement by virtue of their own nature - just like the heavens". ${ }^{26}$ Thus, the sphere of fire does not possess either lightness or heaviness, which means that it can move downwards and upwards. Philoponus tries to prove that even if the heavens, being themselves a sphere of fire, did possess lightness, they would not be able to move upward, since they exhaust the place, filled by the cosmos; the heavens cannot move upward, because they do not have a place for such movement, since the heavens are the extreme sphere of the cosmos. ${ }^{27}$

Insisting that the heavens are made up of fire, Philoponus relies on the word of Plato and on subsequent Neoplatonist critics of the aether theory. Plato and

23 Simplicius, In de Cael., 70, 2-8.

24 Here Philoponus continues the tradition of Plato, Xenarchus, Ptolemeus, Plotinus and Themistius, whereas Simplicius and Alexander Aphrodisias defended their Aristotelian position that a totality of elements in their own place possess lightness and heaviness.

25 Simplicius, In de Cael., 74, 20-26, cited in transl. by J. Wildberg in: C.J. Wildberg, Philoponus: Against Aristotle, pp. 62-63.

26 Ibid., 34, 7-9, cited in transl. by J. Wildberg in: C.J. Wildberg, Philoponus: Against Aristotle, p. 47 .

27 Ibid., 76, 1-10. 
later on Plotinus ${ }^{28}$ and Proclus ${ }^{29}$ did speak of the fact that the heavens are made up of fire with bits of other elements, and Philoponus agrees with this. However, whereas for the Neoplatonists it is important to show a fundamental separateness of the celestial from the terrestrial (that is why they insist that celestial fire is different from the sublunary one and elements that are mixed to the celestial fire are the most perfect parts of terrestrial elements), Philoponus says that the celestial sphere is made up of the same terrestrial fire or, to put in in another way, the heavens do not differ from sublunary things in their matter. Since the heavens are made up of elements, they possess the same qualities as other sublunary things: "[The Grammarian] is campaigning to place heat and coldness, dryness and wetness, softness and hardness as well as the other tangible and perceptible qualities". ${ }^{30}$ In addition, Philoponus points out to the fact that the heavens have other qualities which are equally inherent to sublunary things, such as: transparency, various colors, which are similar to colors of the sublunary world, spherical volume, which other sublunary bodies also possess, tangibility and three-dimensionality. ${ }^{31}$

The unity of celestial and terrestrial matter is supported by Philoponus' teaching on three-dimensionality, which he considers to be prime matter or the first substrate of all bodies. For Philoponus, the Aristotelian understanding of matter as substrate, deprived of any qualities or any definition, is meaningless. ${ }^{32}$ Instead, he uses the Aristotelian notion of body as a thing that possesses magnitude and extends in three dimensions, ${ }^{33}$ and treats three-dimensionality as the first quality of matter. Thus, Philoponus puts forward the notion of three-dimensionality as the first substrate, while defining matter as a threedimensional body, deprived of any other qualities, and which, being unchangeable, underlines of every other body. ${ }^{34}$ Corporeality defined through three-dimensionality makes matter not only the principle of composite thing but also a definite something. First matter, then, is understood not only as the principle in the Aristotelian sense, i.e. as something that can be seen as something separate only mentally, but also as an unqualified body, which by its na-

\footnotetext{
28 Plotinus, Enneades, II, 1,4; 6,11.

29 Cf. С.В. Месяц, “Дискуссии об эфире в античности”, p. 95-96; C.J. Wildberg, Philoponus' Criticism, p. 173 . Simplicius, In de Cael., 87,29 - 88,2, cited in transl. by J. Wildberg in: C.J. Wildberg, Philoponus: Against Aristotle, p. 73.

$31 \quad$ Ibid., 89, 1-25.

32 F. de Haas, John Philoponus' New Definition, p. 289.

33 Aristotle, De Cael., 268a 5-11.

34 F. de Haas, John Philoponus' New Definition, pp. 253-254.
} 
ture underlines of all composite things. ${ }^{35}$ Corporeal extension is considered as a substrate of elementary bodies' qualities and of each material thing:

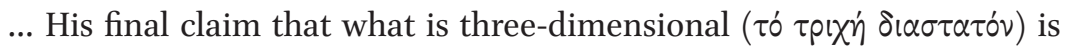
identical in the heavenly bodies and in things in our region. For no threedimensional thing will differ from another in so far as it is three-dimensional, just as no body will differ from another insofar as it is a body. ${ }^{36}$

Whereas the Aristotelian determination of prime matter as something deprived of any definition could not be the common middle term of comparison between the celestial and the terrestrial, Philoponus' three-dimensionality as the principle of any material thing allows to understand every thing (both celestial and terrestrial) first and foremost as a finite body. The definition of matter as a three-dimensional body becomes the common ground for discussing the homogeneity of all spheres of the universe.

The notion of the heavens as a finite body can be seen in the way Philoponus argues for the destructibility of the heavens, thereby replying to Aristotle argument, according to which everything that is generated from and is corrupted into an opposite. ${ }^{37}$ Aristotle distinguishes between the sublunary sphere, in which bodies possess opposite qualities and change to an opposite, and the celestial sphere, which is removed from the opposites; he also thinks that since the heavens do not have any opposite movements, they could not have been generated and cannot be destroyed. Philoponus argues that even if the heavens do not have opposite qualities, which could be a causes of opposite movements, it is nevertheless composed of form and privation as two opposites just like any other finite body:

For with a view to showing that Aristotle says that the heavens have no contrary in the proper sense of the world, [the Grammarian] tries to prove this on [the assumption] that the heavens possess an opposing privation. For he says that Aristotle would not have held that the heavens did not possess any contrary [at all], given that he called 'privation' a contrary. ${ }^{38}$

35 C.J. Wildberg, Philoponus' Criticism, p. 233.

36 Simplicius, In de Cael., 89, 22-25, cited in transl. by J. Wildberg in: C.J. Wildberg, Philoponus: Against Aristotle, p. 74.

37 Ibid., 121, 4-9.

38 Ibid., 121, 25-30, cited in transl. by J. Wildberg in: C.J. Wildberg, Philoponus: Against Aristotle, p. 80. 
According to Philoponus, the very fact of being composed of matter and form as the condition for the existence of a thing supposes the finitude of this existence. Therefore, despite the fact that their matter is not corrupted during movement, the heavens are ontologically finite precisely because they are a composite thing. Since celestial sphere according to its own matter are no different from the terrestrial region, Philoponus draws the conclusion that the heavens, like any other things, by their very nature are subjected to generation and corruption, which means that they were created at some point and will be destroyed along with the rest of the world.

\section{The Heavens as Part of Order of the Universe}

According to Philoponus' reasoning on the relationship of elements in the cosmos, ${ }^{39}$ if the celestial and sublunary spheres do not radically differ, then the heavens do not determine the order but are a part of it; order is then determined by nature as the cause of other elements' movement. According to Aristotle, lightness and heaviness are not relative but are substantial qualities of elements. Hence, the ability to move upward or downward constitute the nature of an element and cannot be taken out of its definition. Lightness and heaviness are described as a natural inclination toward its own place and that is why elemental motion is determined by the order of places in the cosmos. In the Commentaries on Aristotle's 'Physics' Philoponus criticizes the opinion of the Stagirite, according to which place has power, ${ }^{40}$ by pointing out that a place by itself does not have power and does not cause movement. ${ }^{41}$ According to Philoponus, the cause of elemental motion is its nature, which he describes as an inner mover or a natural inclination $(\varphi v \sigma \omega x \eta \dot{~} \rho 0 \pi \eta \dot{\eta}){ }^{42}$ In discussing the nature in his commentary on the 2nd book of Physics, Philoponus defines natural things as those that have an inner mover as the cause of its own movement and differentiates it from non-natural things, created through art or have the mover outside of themselves. By 'inner mover' Philoponus primarily means the soul, while understanding the natural movement of inanimate bodies by analogy with the movement of animate things ${ }^{43}$ Aside from inner power, Philoponus points to inclination towards order given by the Creator as the source of

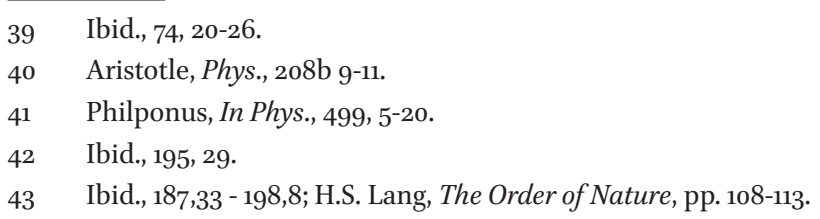


elemental motion: "It is not through desire for a surface that things move each to its proper place, but through desire for that station in the order which they have been given by the Creator". 44

However, Philoponus argues that the order of elemental places itself is not a reason but is a consequence of elemental motion, i.e. it does not determine the motion but instead, is determined by it. The proper place is no longer the place of elemental completeness but is itself defined through bodies, which are moved by an inner mover: "Even if above and below and the other directions also exist relatively to us, they are nevertheless also there in the universe by nature, distinguished in accordance with the motions of the natural body" 45 Thus, a natural inclination of an element causes its lightness or heaviness, and the latter become the reason for correlation of elements within the cosmos; this correlation is seen in the correlation of natural places and the speed of bodies' movement to their places (the heavier the body - the fast it moves):

Just as in the case of the four elements: even if rectilinear movement is one in genus, there still exists, since the [movement] away from the centre is different in species from the [movement] towards the centre, a difference in species between fire and earth because of this; in the same way since there is a difference in species between westward and eastward movement, the moving [bodies] will also be different]. And the planets, if they indeed differ naturally in speed from one another, as earth and water do although they posses the same downward momentum, differ in species because of being faster and slower. ${ }^{46}$

Thus, the cosmic order is understood not as a correlation of places, but as a correlation of simple bodies and is determined by the elemental motion and its speed. ${ }^{47}$ The difference in movement become the cause of difference in the

44 Philoponus, In Phys., in: H.Vitelli, Philoponi In Aristotelis Physicorum libros quinque posteriores commentaria (Commentaria in Aristotelem Graeca, XVII), Berlin, 1888, p. 581, 19-21, cited in transl. by D. Furley in: D. Furley and C.J. Wilberg, Philoponus: Colloraries on Place and Void with Simplicius: Against Philoponus on the Eternity of the World, London-New York, 2014, p. 44.

45 Ibid., 500, 3-5, cited in transl. by K. Algra and J. van Ophuijsen in: K. Algra and J. van Ophuijsen, Philoponus On Aristotle Physics 4.1-5, London-New York, 2012, p. 20.

46 Simplicius, In de Cael., 31, 7-14, cited in transl. by J. Wildberg in: C.J. Wildberg, Philoponus: Against Aristotle, p. 46.

47 H.S. Lang, The Order of Nature, pp. 120-121; C. Scholten C. Antike Naturphilosophie, pp. 199200. 
cosmic places, while the direction and the speed of movement arranges bodies in these places.

\section{Conclusion: On the Notion of Element in the Cosmology of Aristotle and Philoponus}

On one hand, Philoponus tries to prove that the celestial and sublunary spheres do not differ in their matter, thereby rejecting the Aristotelian aether theory and deducing the fundamental finitude and createdness of the heavens. On the other hand, he believes that elemental motion is the reason for order of places in the cosmos. In these discussions, Philoponus' conceptual vocabulary is quite different from Aristotle's one.

Aristotle understands elements not as bodies but more as a combination of simple qualities. If the prime matter is seen as an indefinite principle, elements are then understood as matter, defined through its simple qualities. Sublunary elements as such are not bodies but are part of bodies, while matter of any moving body is a mixture of elements. The nature of each element is described as a set of qualities and furthermore, if one element changes, the nature changes along with it. For instance, fire combines within itself warmth, dryness, lightness; air combines warmth, wetness and lightness. If air loses its wetness, it becomes fire. Furthermore, according to Aristotle the simplicity of elements leads to the invariability of their qualities. Philoponus rejects indefiniteness of Aristotle's first matter and defines it as a body without qualities or three-dimensionality. Thus, matter is not the cause of possibility to exist one or another way or striving for form but is, instead, the beginning of corporeality, defined through magnitude. Elements limit this three-dimensional corporeality by adding to it perceptible qualities. At the same time, they are thought of as bodies with different qualities. Such understanding allows for variation in elemental qualities: an element can have two natural movements and moves in a way that depends on its place.

According to Aristotle, the proper place of an element is determined by the cosmic order, which, in turn, depends on the difference between the celestial and sublunary spheres. The heavens (or to be more precise - the first heaven, according to Aristotle) being in some sense a divine thing determines the order on one hand, and the difference of places on the other, acting as an external cause of natural movements. Thus, the elemental motion according to Aristotle is determined by a proper place, while the inclination of elements toward a place is determined by their nature. However, the elemental motion does not only depend on their nature but also on external movers. "Everything that is in 
motion be moved by something", 48 and this "something" being a mover must itself be in motion. For this reason, although Aristotle defines nature as an intrinsic source of movement, a natural thing, when moving, it becomes a part of causal series that cause movement within the cosmos, ${ }^{49}$ where one thing is moved by another and at the same time acts as a moving cause. The heavens act as the first moving mover and as the cause of movement for all sublunary things. By contrast for Philoponus the order of places in cosmos is determined by the elemental motion and consequently, by nature as the inner principle of such movement. According to him, nature is an internal cause of motion, which does not depend an external mover. ${ }^{50}$ Whereas for Aristotle the eternal celestial motion is the first efficient cause, which provide continuity of motion in the universe, for Philoponus any natural thing in this sense can be autonomous. Thus, the account of matter as a three-dimensional extension, common to all moving bodies and the account of elemental nature, which defines its place in the universe and could cause different (but not contrary) motions, allows Philoponus to align the heavens with other moved things. Since celestial matter, celestial motion and its cause do not differ from sublunary matter and motion, the heavens, just like sublunary things, can be generated and destroyed.

48 Aristotle, Phys., 256a, 13-14, cited in transl. by D.W. Graham in: D.W. Graham, Aristotle Physics Book VIII, New York 1999, p. 12.

49 Cf. Aristotle, Phys. 259a 29 - 259b 1, 267a $21-267$ b 1.

$50 \quad$ Philoponus, In Phys, 197.33 - 198.8, 678,22 cff., 679, 27 cff.; cf. H.S. Lang, The order of Nature, pp. 108-111; M. Wolff, M. Philoponus and the Rise of Preclassical Dynamics, pp. 135-137. The nature itself is understood as something created and in this sense depends on the creator; moreover, in Contra Proclum Philoponus understands nature as the moving force, which is put by God into every being. This topic, however, needs a separate analysis. 